\title{
Classical Criminological Perspective and Attitudes Toward Same-Sex Rights
}

\author{
Abu MBoka, Ph.D. \\ California State University, Stanislaus \\ Sriram Chintakrindi, Ph.D. ${ }^{1}$ \\ California State University, Stanislaus \\ Chau-Pu Chiang, Ph.D. \\ California State University, Stanislaus \\ Phyllis Gerstenfeld, Ph.D. \\ California State University, Stanislaus \\ Dorothy McClellan \\ Texas A \& M University, Corpus Christi \\ Irma Kovčo Vukadin, Ph.D. \\ University of Zagreb
}

Abstract

This study examined the degree to which perspectives consistent with classical criminological theory among college students and faculty supported public and governmental responses to same-sex rights (e.g., gay marriage). Classical criminology assumes that "crime is the product of a person's free will" and "the main reason why people break the law is that they figure they can get away with it". A convenience sample of 1471 undergraduate and graduate students, and college and university professors in the United States, Eastern Europe, Asia, and other unidentified countries completed a survey (via SurveyMonkey) between 2014 and 2015. The data failed to support our hypothesis that people who supported classical criminology were likely to see the issue of same-sex interaction as a non-rule violation and that same-sex rights should be provided. Bivariate analyses instead indicated that classical criminology perspectives did not support attitudes endorsing same-sex rights. One explanation is that people who support classical criminological perspective are more likely to be political conservative and religious, two characteristics that tend to disapprove homosexuality and, thus, less likely to support same-sex rights.

Keywords: classical criminological theory; classical criminological theorists; same-sex rights; positive rights and negative rights. 
Abu MBoka, Sriram Chintakrindi, Chau-Pu Chiang, Phyllis Gerstenfeld, Dorothy McClellan, Irma Kovčo Vukadin: Classical Criminological Perspective and Attitudes Toward Same-Sex Rights

\section{INTRODUCTION}

Understanding the different theoretical worldviews that shape positions on same-sex rights and sexual interaction is important because studies show that in most countries, public "policies generally reflect the ideologies and beliefs of a state's citizens", and public support for same-sex marriage is a predictor of court decisions, public policies, and legislative outcomes (Lewis and Oh 2008, p. 51). Research in this area also provokes thoughtful reactions about whether or not sexual orientation and gender expression are legitimate qualifications for subjecting certain groups of people to socially-sanctioned and state-facilitated prejudice, discrimination, marginalization, and financial and psychological victimization and pain.

Matters relating to the rights of gays and lesbians are no longer a matter of concern for only gays and lesbians confined within a particular national border. Even in countries with comparatively healthy civil right records like the United States, the call for validation of the rights of same-sex people to marry, the appeal for public acceptance of same-sex sexual practices as natural human sexual behaviors, and the demand for the rights to the same legal recognition and protection heterosexual couples enjoy remain contentious and informed by events happening outside local borders (Williams, 2011; Hackl, Boyer et al., 2013; Woodford, Atteberry et al. 2013). In addition to 75 countries where same-sex sexual acts remain illegal, many nations like Nigeria, Russia, and Uganda are also currently occupied with the litigation of same-sex rights and questions about protecting or not defending same-sex relationships (Carroll and Itaborahy 2005; Chamie and Mirkin, 2011, Koroma and Baker 2005; Banks 2014). Collectively, these developments create a strong need for developing some understanding of the frames of mind that inform individual attitudes towards same-sex interactions and rights.

Our review of literature shows that the contributions of research to the understanding of same-sex sexual interactions, right to marriage, and equal treatment remain concentrated around competing discussions of the types of rights and recognition to which same-sex couples are entitled, those who support or object to the recognition of the rights of same-sex couples to marry, and the impact of public opinion, attitudes, religiosity and moral ideology on legislative outcomes that 
Abu MBoka, Sriram Chintakrindi, Chau-Pu Chiang, Phyllis Gerstenfeld, Dorothy McClellan, Irma Kovčo Vukadin: Classical Criminological Perspective and Attitudes Toward Same-Sex Rights

affect gays and lesbians (Lewis and Oh, 2008; Williams, 2011). However, despite broad academic work in these areas, the focus of research on factors that inform the many underlying opinions and attitudes regarding same-sex interaction and risk remains significantly inadequate.

We examine the degree to which undergraduate criminal justice related majors with classical views of why people commit crimes support or object to public and state responses to same-sex interactions and rights. In light of this goal, classical views and beliefs are discussed in terms of how they are informed by rational choice theory and procedural fairness. Finally, explanation of why classical criminological theorists are likely to see the issue of same-sex interactions and rights as harmless matters of individual rights that should be simply respected are also provided. In this regard, a classical criminological theorist is understood as a person who believes that a "crime is the product of a person's free will" and that "the main reason why people break the law is that they figure they can get away with it."

\section{LITERATURE REVIEW OF CRIMINALIZATION AND LEGALIZATION OF SAME-SEX SEXUAL INTERACTIONS}

One prominent characteristic of classicists is the shared belief that those who violate laws do so out of free will and therefore must face proportionate sanctions. The imposition of sanctions is guided by the concept of objectivity and equal treatment of people under similar conditions and in accordance with established procedures in order to prevent acts of injustice, promote procedural fairness and to guarantee just outcomes (Solomon and Murphy, 2000; Maiese, 2013). For these reasons classical criminological theorists look to existing law (both domestic and international depending on the issue) for guidance to ensure procedural fairness and just conclusions.

In the case of same-sex sexual interactions and rights, however, there is currently no standing international instrument for guidance regarding the prohibition or recognition of same-sex sexual interaction and rights. For instance, Article 16 of the Universal Declaration of Human Rights, the 
Abu MBoka, Sriram Chintakrindi, Chau-Pu Chiang, Phyllis Gerstenfeld, Dorothy McClellan, Irma Kovčo Vukadin: Classical Criminological Perspective and Attitudes Toward Same-Sex Rights

most relevant international instrument on this matter, does not categorically protect or prohibit same-sex interactions (1948). The Article reads as follows:

(1) Men and women of full age, without any limitation due to race, nationality or religion, have the right to marry and to found a family. They are entitled to equal rights as to marriage, during marriage and at its dissolution.

(2) Marriage shall be entered into only with the free and full consent of the intending spouses.

(3) The family is the natural and fundamental group unit of society and is entitled to protection by society and the State.

A plain reading of this article shows that gender is excluded from the list of protected categories like race, nationality or religion. On the other hand, Article 16 limits the "right to marry and to found a family" to marriage between "men and women" and thus fails to prohibit discrimination on the basis of sexual orientation. Similarly, Article 10 of the International Covenant on Economic, Social and Cultural Rights (1966) deals with only the freedom to marry (marriage must be entered into with the free consent of the intending spouses), and not who is entitled to marry (1966).

The right to same sex marriage is also only recognized in twenty countries and 13 of those countries, including the United States, did so only in the last five years. Indeed the recent United States Supreme Court's ruling that the 14th Amendment to the United States Constitution requires "a State to license a marriage between two people of the same sex" (2015) has had and will continue to have a strong impact on public opinion and policies within the jurisdiction of the United States. 
Abu MBoka, Sriram Chintakrindi, Chau-Pu Chiang, Phyllis Gerstenfeld, Dorothy McClellan, Irma Kovčo Vukadin: Classical Criminological Perspective and Attitudes Toward Same-Sex Rights

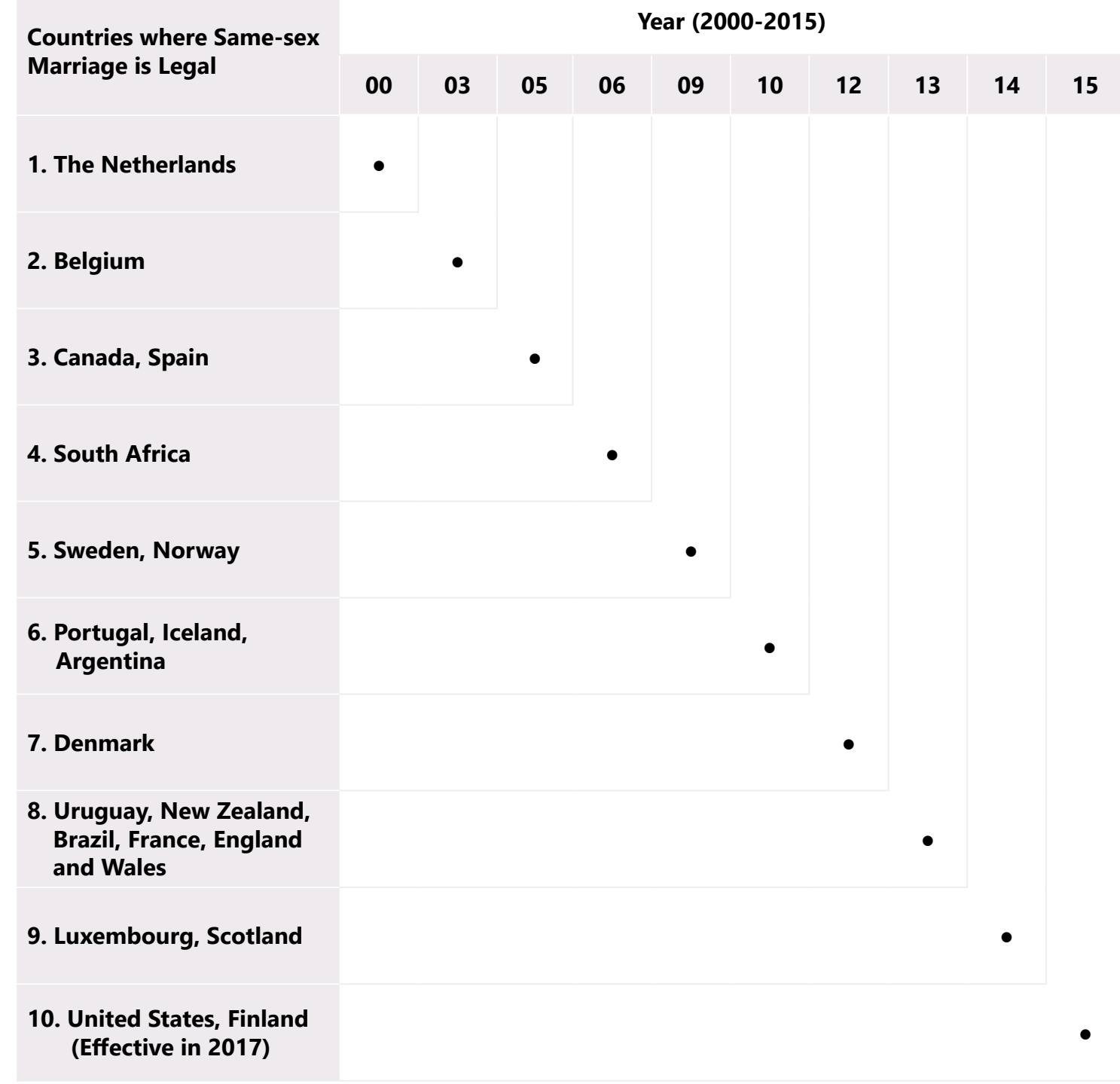

It however remains to be seen how the United States Supreme Court's holding will impact decisions in the remaining 173 United Nations member-countries that still maintain local laws that do not recognize or legalize, but do in some cases criminalize, same-sex marriage or sexual encounters. Of course given the influence of American foreign aid, the best prediction is that the ruling in Obergefell et al. V. Hodges, Director, Ohio Department of Health, et (2015) is likely to 
Abu MBoka, Sriram Chintakrindi, Chau-Pu Chiang, Phyllis Gerstenfeld, Dorothy McClellan, Irma Kovčo Vukadin: Classical Criminological Perspective and Attitudes Toward Same-Sex Rights

inform American foreign policies and development aids which in turn will predictably influence legislative outcomes outside the borders of the United States. Meanwhile, the attitudes and opinions of people, in terms of legality as a point of reference, in most countries, including the United States, or regions of the world on the issue of same-sex sexual interactions and rights remains unguided by international law (McCarthy, 2015).

\section{COMPETING POSITIONS ON SAME-SEX INTERACTIONS AND RIGHTS}

In the absence of international laws and global recognition of same-sex sexual interactions and rights, questions about same-sex interactions and rights are inevitably bound to generate answers that are heavily influenced by factors like the rational basis of support for or objection to the recognition of same-sex sexual interactions and the extension of rights to same-sex couples. Such questions are also likely to invoke notions of fairness and justice and to invite extralegal reasoning. For example, many extralegal and theoretical interpretations of the kind of rights gays and lesbians pursue or qualify for have been advanced in recent years (Holzer, 2014). As a result, however, though the issue of same-sex sexual interactions and rights is less complicated from a rational standpoint and when viewed within the context of similarly recognized negative and positive rights, competing attitudes and opinions continue to hold.

Proponents of same-sex sexual interactions and rights argue that throughout, at least in recent human history, marriage has been restricted to a relationship between men and women because such unions promote procreation, which establishes parenthood and families that ensure the continuous production of legitimate offspring to guarantee the expansion of the human race (Chamie and Mirkin 2011, p. 540). Those who support same-sex sexual interactions and rights to marriage share the view that such recognition simply "permits individuals to exercise what is deemed their fundamental human right to marry the person of their choice" (Chamie and Mirkin 2011, p. 538). 
Abu MBoka, Sriram Chintakrindi, Chau-Pu Chiang, Phyllis Gerstenfeld, Dorothy McClellan, Irma Kovčo Vukadin: Classical Criminological Perspective and Attitudes Toward Same-Sex Rights

The phrases "same-sex marriage" and "same-sex rights" that are generally used in key literature on this subject (Veigh and Diaz 2009; Gaines and Garand, 2010; Williams, 2011) are umbrella phrases that invoke at least two distinct sets of rights-negative rights and positive rights. The real questions therefore are whether or not (1) the ability of gays and lesbians to satisfy their intimate desires through same-sex sexual interactions are functions of their natural biological makeup, (2) same-sex sexual interactions are not sufficient grounds for state-sanctioned denial of protection against discriminatory policies and practices, and (3) whether or not marriage between people of the same-sex invalidate states' obligations to protect their voters and tax-payers. Obviously, these questions demand affirmative responses because each one of them invokes a negative or positive right.

Negative rights, sometimes referred to "non-interventionist" rights (Hirschl, 2000, p. 1063), place no obligation on another person to provide goods or services; thus, states are required to respect the enjoyment of such rights as long as the exercise of such inherent rights does not encroach upon the rights of another person. These rights include the right to life, liberty, and the pursuit of happiness, which includes the right to sleep with, form opinions about, and to engage in sexual behaviors among others. Because these rights are functions of biological needs that can be satisfied without external assistance, there is no basis for government coercion or for governments to engage in conduct that endorses, favors, advances, or disparages their peaceful exercise (Green, 2007, p. 1456).

Matters relating to individual sexuality or sexual orientation fall under the category of negative rights because individual sexual orientation is first and foremost a biological function that does not require any external resources, unless it is motivated by the need to reproduce. Therefore, the subjection of the exercise of such rights to unfavorable private attitudes and state-sanctioned policies that legitimize or promote prejudice, discrimination, marginalization, and financial and psychological victimization are hard to justify. The same conclusion can be reached about co-negative rights.

The exercise of certain negative rights like the right to assemble or participate in religious services may require the cooperation of another person, thereby rendering them co-negative 
Abu MBoka, Sriram Chintakrindi, Chau-Pu Chiang, Phyllis Gerstenfeld, Dorothy McClellan, Irma Kovčo Vukadin: Classical Criminological Perspective and Attitudes Toward Same-Sex Rights

(two) rights because their enjoyment becomes contingent upon the full cooperation of another consenting negative right holders (persons). However, the mere merging of two or more negative rights by two or more people in pursuit of mutual interests does not invalidate the legitimacy of a negative right. Same-sex sexual interaction is therefore a co-negative rights of two consenting adults and are analogous to the right to peaceful assembly, group worship, and communication. Just as a communicator needs another communicator to communicate, a protester needs another willing protester to assemble, and a believer needs another believer to engage in group worship, a lesbian needs another lesbian to form a common union.

Negative rights can also become positive rights if the enjoyment of such rights is entirely dependent on the support of a third party, in this case the government. For example, when individuals ask for protection to peacefully assemble, when they apply for permit to build a place of worship, or assert rights to education or medical treatment, they are demanding positive rights-rights that cannot be enjoyed without the support of public resources or a third party. The enjoyment of the rights to primary and secondary education or medical treatment, for instance, are conditioned upon the availability and willingness of teachers and doctors along with educational and medical administrators and assistants and the use of materials that are produced by other people.

Positive rights obligate third parties to provide services or resources that are needed to ensure their fulfillment by the right holders because without the external services or supports, the positive right holders cannot enjoy their rights (Hirschl, 2000; Green, 2007; Bradley, 2010; David, 2014). Therefore, the demands for same-sex marriage recognition fall under the category of positive rights because in essence state recognition of same-sex unions extends the privileges and protections (third party services) heterosexual couples enjoy. In another words, the rights to engage in same-sex sexual activities are negative rights but the rights for same-sex couples to enjoy the services heterosexual couple enjoy are positive rights because the latter demands third party actions while the formal only require the participation of same-sex or opposite-sex couples. 
Abu MBoka, Sriram Chintakrindi, Chau-Pu Chiang, Phyllis Gerstenfeld, Dorothy McClellan, Irma Kovčo Vukadin: Classical Criminological Perspective and Attitudes Toward Same-Sex Rights

\section{RESEARCH QUESTION AND HYPOTHESES}

We ask whether individuals who support the classical criminological perspectives are more likely to also support homosexual rights? In societies where individual and collective rights are respected, the exercise of negative and positive rights is facilitated and protected as long as the exercise of such rights produces no foreseeable damage to innocent parties. Obviously, it is evident by now that as far as same-sex interactions and marriage are concerned, there is no evidence of harm being committed against innocent citizens. Therefore, we deduce that those individuals who support the classical criminological perspective are likely to view the idea of depriving or imposing sanctions on certain groups of people for committing no harm or crime against others as lacking procedural fairness and being inconsistent with classical reasoning, and to possess attitudes that recognize the legitimacy of same-sex interactions. Therefore, we hypothesize that our data will support the following statements:

H1. Individuals who support the classical criminological perspective would strongly agree with statements supporting homosexual rights.

H2. Individuals who support the classical criminological perspective would disagree with statements that prohibit or denounce homosexual rights.

\section{METHODS}

We use a convenience sample $(N=1471)$ of primary source survey respondent data that was collected from undergraduate, graduate students, and educators from six different countries. All survey respondents participating in this study were 18 years or older and affiliated with a college or university. The instrument used in this study provides a comparative examination of university students' attitudes about two subjects: punitive versus rehabilitative approaches to criminal behavior, and the rights of gay and lesbian people (Gerstenfeld et al., 2015). Data was collected using SurveyMonkey online survey platform and printed copies. 
Abu MBoka, Sriram Chintakrindi, Chau-Pu Chiang, Phyllis Gerstenfeld, Dorothy McClellan, Irma Kovčo Vukadin: Classical Criminological Perspective and Attitudes Toward Same-Sex Rights

\section{Classical Criminological Statements}

We examine support for the classical criminological perspective by examining respondent ratings to the following statements: (1) Crime is the product of free will and (2) The main reason why people break the law is that they figure they can get away with it. Statements are on a Likert scale and continuously coded ( $1=$ Strongly agree and 5 = Strongly disagree).

\section{Dependent Variables}

We examine support for gay and lesbian rights by examining respondent ratings to the following statements: (1) A woman's homosexuality should not be a cause for job discrimination in any situation, (2) Laws regarding private consenting lesbian behavior should be loosened, (3) Female homosexuality in itself is no problem, but what society makes of it can be a problem, (4) Male homosexual couples should be allowed to adopt children the same as heterosexual couples, (5) Just as in other species, human male homosexuality is a natural expression of sexuality, (6) Male homosexuality is merely a different kind of lifestyle that should not be condemned, (7) Female homosexuality is a threat to many of our basic social institutions, (8) Male homosexuals should not be allowed to teach school, (9) Homosexual behavior between two men is just plain wrong, and (10) The idea of homosexual marriages seems ridiculous to me.

All of the statements are on a Likert scale and continuously coded ( $1=$ Strongly disagree and $5=$ Strongly agree).

In addition, we conducted two separate factor analyses of different sets of items, listed above, to determine whether there are unidimensional and latent constructs of negative and positive attitudes towards homosexual rights. The exploratory factor also includes a reliability analysis that allowed for the examination of the internal consistency of the different sets of items. 
Abu MBoka, Sriram Chintakrindi, Chau-Pu Chiang, Phyllis Gerstenfeld, Dorothy McClellan, Irma Kovčo Vukadin: Classical Criminological Perspective and Attitudes Toward Same-Sex Rights

The first factor analysis examines latent construct for positive attitude statements towards homosexual rights using items: 1, 2, 3, 4, 5, and 6. The factor score for the positive attitudes statements towards homosexual rights indicates that the 6 -items have an alpha reliability of 0.76 and that the one factor solution explains $46.4 \%$ of the total variation in those items as a linear combination. The second factor analysis examines a latent construct for negative attitude statements towards homosexual rights using items: 7, 8, 9, and 10. The factor score for the negative attitude statements towards homosexual rights indicates that the 4-items have an alpha reliability of 0.87 and that the one factor solution explains $73.6 \%$ of the total variation in those items as a linear combination.

\section{Control Variables}

This study includes ten control variables that include social demographic characteristics, sexual characteristics, education, political and religious orientation, location of respondent, and respondents' attitudes towards punitive punishments. These variables measure the strength of the relationship between predictor and outcome variables when testing multiple regression models.

The social demographic characteristics measure: (1) age and (2) gender. Age is a continuously coded ratio-level variable. Gender is a dichotomously coded nominal-level variable $(0=$ Female and $1=$ Male). The sexual characteristics measure: (1) self-reported sexual orientation and (2) whether they have gay or lesbian friends. Sexual orientation is a dichotomously coded nominal-level variable $(0=$ Homosexual and $1=$ Heterosexual), whether the respondent has gay or lesbian friends is a dichotomously coded nominal-level variable $(0=$ No and $1=$ Yes).

Educational characteristics measure college degree major, which is dichotomously coded nominal-level variable $(0=$ Social Sciences, Arts, or Humanities and $1=$ Criminal Justice or Legal Studies). The political and religious orientation characteristics measure: (1) political orientation, (2) religious beliefs, and (3) frequency of religious attendance. Political orientation variable measure on a Likert scale that is continuously coded ( $1=$ Extremely Liberal and $7=$ Extremely Conservative). The religious beliefs variable on a Likert scale that is continuously coded $(1=$ Not at all and $4=\mathrm{A}$ 
Abu MBoka, Sriram Chintakrindi, Chau-Pu Chiang, Phyllis Gerstenfeld, Dorothy McClellan, Irma Kovčo Vukadin: Classical Criminological Perspective and Attitudes Toward Same-Sex Rights

great deal), and the frequency of religious attendance is continuously coded ( $1=$ Not religious and $6=$ More than once a week).

Respondents' location is measured using geographical location of their domicile, and four different dummy variable indicators of geographical location (North America, Eastern Europe, Asia, and Other). The dummy variables consist of respondents from North America (the U.S.) Eastern Europe (Croatia, Russia, and Macedonia) Asia (Japan, Taiwan, and India) and others (geographical location not reported).

We used an additive scale, to control for attitudes towards punitive punishment policies, that consists of 15-items: (1) Driving a car under the influence of alcohol, (2) Stealing something up to $\$ 350$, (3) Breaking into a home with intent to steal something, (4) Hitting an adult hard enough that he or she needs medical attention, (5) Shoplifting something worth up to $\$ 65$, (6) Using heroin, (7) Rape, (8) Assisting someone in suicide, (9) Purse snatching, (10) Stealing a car, (11) Injuring someone with a knife or gun, (12) Beating one's own child severely enough that the child requires medical attention, (13) Hitting a gay or lesbian person (because of their sexual orientation) hard enough that he or she needs medical attention, (14), Husband raping a wife, (15) Terminating an unwanted pregnancy (abortion). The scale examined respondents' support for the use of punitive punishments, and each measure is on a Likert scale and are continuously coded, nominal-level variable ( $1=$ No government response to $9=$ Long term imprisonment). Scores for indicator are added to together to create a total additive score for each respondent that is indicative of supporting punitive punishment policies. 
Abu MBoka, Sriram Chintakrindi, Chau-Pu Chiang, Phyllis Gerstenfeld, Dorothy McClellan, Irma Kovčo Vukadin: Classical Criminological Perspective and Attitudes Toward Same-Sex Rights

\section{Data Analysis}

We conducted descriptive statistics that demonstrate aggregate percentages and means for independent, control, and dependent variables. We also conduct bivariate analysis of the independent and dependent variable factor scores using Pearson's $r$ correlation analysis. We further conducted series of multivariate analyses using multiple regression approach to examine theoretically specified model of support for the classical criminological perspective and its ability to predict factor score outcomes for attitudes towards homosexual rights. Using a multiple regression test, we examined predictor and control variables and their relationship with our factor score outcomes using two different models. The R-square and statistically significant unstandardized coefficients of predictor and control variables in multiple regression models are briefly discussed. Each multiple regression models include control variables: age, gender, sexual orientation status, gay or lesbian friend status, college major, political orientation, role of religion, frequency of religious service attendance, geographic regional origin, and support for punitive punishments. 
Abu MBoka, Sriram Chintakrindi, Chau-Pu Chiang, Phyllis Gerstenfeld, Dorothy McClellan, Irma Kovčo Vukadin: Classical Criminological Perspective and Attitudes Toward Same-Sex Rights

\section{RESULTS}

The descriptive statistics for statements that reflect respondents' support for classical criminological perspective, and attitudes towards gay and lesbian rights are discussed. Further, how respondents' level of agreement correlated with the theoretical statements, respondents' attitudes towards homosexual rights, and summaries of the multivariate models are provided and discussed.

Table 1. Descriptive Statistics for Classical Criminological Perspectives

\begin{tabular}{|c|c|c|c|c|c|c|}
\hline \multirow[t]{2}{*}{ Predictor variables } & $\begin{array}{l}\text { Strongly } \\
\text { disagree }\end{array}$ & Disagree & $\begin{array}{l}\text { Neither } \\
\text { agree } \\
\text { nor } \\
\text { disagree }\end{array}$ & Agreee & $\begin{array}{l}\text { Strongly } \\
\text { agree }\end{array}$ & Missing \\
\hline & n (\%) & n (\%) & n (\%) & n (\%) & n (\%) & n (\%) \\
\hline $\begin{array}{l}\text { Rational choice Theory } \\
\text { Statements } \\
\text { 1. Crime is the product of a person's } \\
\text { free will. }\end{array}$ & $\begin{array}{c}52 \\
(3.5)\end{array}$ & $190(12.9)$ & $\begin{array}{c}313 \\
(21.3)\end{array}$ & $\begin{array}{c}579 \\
(39.4)\end{array}$ & $\begin{array}{c}169 \\
(11.5)\end{array}$ & $\begin{array}{c}168 \\
(11.4)\end{array}$ \\
\hline $\begin{array}{l}\text { 2. The main reason why people } \\
\text { break the law is that they figure } \\
\text { they can get away with it. }\end{array}$ & $\begin{array}{c}48 \\
(3.3)\end{array}$ & $250(17.0)$ & $\begin{array}{c}297 \\
(20.2)\end{array}$ & $\begin{array}{c}552 \\
(37.5)\end{array}$ & $\begin{array}{c}149 \\
(10.1)\end{array}$ & $\begin{array}{c}175 \\
(11.9)\end{array}$ \\
\hline
\end{tabular}

Table 1 shows that a majority of respondents agree or strongly agree (50.9\%) that "Crime is the product of a person's free will", and $47.6 \%$ of respondents agree or strongly agree that "The main reason why people break the law is that they figure they can get away with it". 
Abu MBoka, Sriram Chintakrindi, Chau-Pu Chiang, Phyllis Gerstenfeld, Dorothy McClellan, Irma Kovčo Vukadin: Classical Criminological Perspective and Attitudes Toward Same-Sex Rights

Table 2. Descriptive Statistics for Attitudes toward Homosexual Rights

\begin{tabular}{|c|c|c|c|c|c|c|}
\hline Outcome Variables & $\begin{array}{c}\text { Strongly } \\
\text { Disagree } \\
\text { n (\%) }\end{array}$ & $\begin{array}{l}\text { Disagree } \\
\text { n (\%) }\end{array}$ & $\begin{array}{c}\text { Neither } \\
\text { agree } \\
\text { nor } \\
\text { disagree } \\
\text { n (\%) }\end{array}$ & $\begin{array}{l}\text { Agree } \\
\text { n (\%) }\end{array}$ & $\begin{array}{c}\text { Strongly } \\
\text { Agree }\end{array}$ & $\begin{array}{l}\text { Missing } \\
\text { n (\%) }\end{array}$ \\
\hline \multicolumn{7}{|l|}{$\begin{array}{l}\text { Positive attitude statements } \\
\text { towards homosexual rights }\end{array}$} \\
\hline $\begin{array}{l}\text { 1. A woman's homosexsuality } \\
\text { should not be a cause for job } \\
\text { discrimination in any situation. }\end{array}$ & $\begin{array}{c}69 \\
(4.7)\end{array}$ & $\begin{array}{c}31 \\
(2.1)\end{array}$ & $\begin{array}{c}65 \\
(4.4)\end{array}$ & $\begin{array}{c}216 \\
(14.7)\end{array}$ & $\begin{array}{c}978 \\
(66.5)\end{array}$ & $\begin{array}{l}112 \\
(7.6)\end{array}$ \\
\hline $\begin{array}{l}\text { 2. Laws regarding private } \\
\text { consenting lesbian behavior } \\
\text { should be loosened. }\end{array}$ & $\begin{array}{c}91 \\
(6.2)\end{array}$ & $\begin{array}{c}89 \\
(6.1)\end{array}$ & $\begin{array}{c}463 \\
(31.5)\end{array}$ & $\begin{array}{c}278 \\
(18.9)\end{array}$ & $\begin{array}{c}433 \\
(29.4)\end{array}$ & $\begin{array}{l}117 \\
(8.0)\end{array}$ \\
\hline $\begin{array}{l}\text { 3. Female homosexsuality in itself } \\
\text { is no problem, but what society } \\
\text { makes of it can be a problem. }\end{array}$ & $\begin{array}{c}92 \\
(6.3)\end{array}$ & $\begin{array}{c}84 \\
(5.7)\end{array}$ & $\begin{array}{c}271 \\
(18.4)\end{array}$ & $\begin{array}{c}497 \\
(33.8)\end{array}$ & $\begin{array}{c}141 \\
(28.1)\end{array}$ & $\begin{array}{l}113 \\
(7.7)\end{array}$ \\
\hline $\begin{array}{l}\text { 4. Male homosexual couples } \\
\text { should be allowed to } \\
\text { adopt children the same as } \\
\text { heterosexual couples. }\end{array}$ & $\begin{array}{c}212 \\
(14.4)\end{array}$ & $\begin{array}{c}93 \\
(6.3)\end{array}$ & $\begin{array}{c}208 \\
(14.1)\end{array}$ & $\begin{array}{c}254 \\
(17.3)\end{array}$ & $\begin{array}{c}583 \\
(39.6)\end{array}$ & $\begin{array}{l}121 \\
(8.2)\end{array}$ \\
\hline $\begin{array}{l}\text { 5. Just as in other species, human } \\
\text { male homosexuality is a } \\
\text { natural expression of sexuality. }\end{array}$ & $\begin{array}{c}111 \\
(7.5)\end{array}$ & $\begin{array}{c}95 \\
(6.5)\end{array}$ & $\begin{array}{c}287 \\
(19.5)\end{array}$ & $\begin{array}{c}301 \\
(20.5)\end{array}$ & $\begin{array}{c}555 \\
(37.7)\end{array}$ & $\begin{array}{c}122 \\
(8.3)\end{array}$ \\
\hline $\begin{array}{l}\text { 6. Male homosexuality is merely } \\
\text { a different kind of lifestyle that } \\
\text { should not be condemned. }\end{array}$ & $\begin{array}{r}120 \\
(8.2)\end{array}$ & $\begin{array}{c}94 \\
(6.4)\end{array}$ & $\begin{array}{c}235 \\
(16.0)\end{array}$ & $\begin{array}{c}277 \\
(18.8)\end{array}$ & $\begin{array}{c}624 \\
(42.4)\end{array}$ & $\begin{array}{c}121 \\
(8.2)\end{array}$ \\
\hline \multicolumn{7}{|l|}{$\begin{array}{l}\text { Negative attitude statements } \\
\text { towards homosexual rights }\end{array}$} \\
\hline $\begin{array}{l}\text { 7. Female homosexuality ia a } \\
\text { threat to many of our basic } \\
\text { social institutions. }\end{array}$ & $\begin{array}{c}821 \\
(55.8)\end{array}$ & $\begin{array}{c}267 \\
(18.2)\end{array}$ & $\begin{array}{c}190 \\
(12.9)\end{array}$ & $\begin{array}{c}59 \\
(4.0)\end{array}$ & $\begin{array}{c}22 \\
(1.5)\end{array}$ & $\begin{array}{l}112 \\
(7.6)\end{array}$ \\
\hline $\begin{array}{l}\text { 8. Male homosexuals should not } \\
\text { be allowed to teach school. }\end{array}$ & $\begin{array}{c}939 \\
(63.8)\end{array}$ & $\begin{array}{c}192 \\
(13.1)\end{array}$ & $\begin{array}{l}133 \\
(9.0)\end{array}$ & $\begin{array}{c}34 \\
(2.3)\end{array}$ & $\begin{array}{c}52 \\
(3.5)\end{array}$ & $\begin{array}{l}121 \\
(8.2)\end{array}$ \\
\hline $\begin{array}{l}\text { 9. Homosexual behavior between } \\
\text { two men is just plain wrong. }\end{array}$ & $\begin{array}{c}763 \\
(51.9)\end{array}$ & $\begin{array}{c}215 \\
(14.6)\end{array}$ & $\begin{array}{c}183 \\
(12.4)\end{array}$ & $\begin{array}{c}93 \\
(6.3)\end{array}$ & $\begin{array}{c}96 \\
(6.5)\end{array}$ & $\begin{array}{l}121 \\
(8.2)\end{array}$ \\
\hline $\begin{array}{l}\text { 10. The idea of homosexual } \\
\text { marriages seems ridiculous } \\
\text { to me. }\end{array}$ & $\begin{array}{c}766 \\
(52.1)\end{array}$ & $\begin{array}{c}199 \\
(13.5)\end{array}$ & $\begin{array}{c}180 \\
(12.2)\end{array}$ & $\begin{array}{c}83 \\
(5.6)\end{array}$ & $\begin{array}{l}121 \\
(8.2)\end{array}$ & $\begin{array}{l}122 \\
(8.3)\end{array}$ \\
\hline
\end{tabular}


Abu MBoka, Sriram Chintakrindi, Chau-Pu Chiang, Phyllis Gerstenfeld, Dorothy McClellan, Irma Kovčo Vukadin: Classical Criminological Perspective and Attitudes Toward Same-Sex Rights

Table 2 shows that on an average $30.6 \%$ of respondents agree, (20.6\%) or strongly agree (40.6\%) with statement 1 through 6, and 35.3\% disagree (14.8\%), or strongly disagree (55.9\%) with statement 7 through 10 respectively.

\section{Table 3. Descriptive Statistics for Control Variables}

\begin{tabular}{|c|c|c|c|}
\hline Variable (Groupings) & n (\%) & $M(S D)$ & Missing n (\%) \\
\hline $\begin{array}{l}\mathrm{N} \\
\text { Predictor variables }\end{array}$ & $1471(100)$ & - & $0(0)$ \\
\hline \multicolumn{4}{|l|}{ Social demographic characteristics } \\
\hline $\begin{array}{l}\text { Age } \\
\text { Gender } \\
\text { Male } \\
\text { Female }\end{array}$ & $\begin{array}{c}- \\
1044(71) \\
411(27.9)\end{array}$ & $26.21(9.70)$ & $\begin{array}{c}21(1.4) \\
21(1.4) \\
-\end{array}$ \\
\hline \multicolumn{4}{|l|}{ Sexual Characteristic } \\
\hline $\begin{array}{l}\text { What is your sexual orientation? } \\
\text { Homosexual } \\
\text { Heterosexual } \\
\text { Do you have any gay or lesbian frien } \\
\text { No } \\
\text { Yes }\end{array}$ & $\begin{array}{c}61(4.1) \\
1207(82.1) \\
406(27.6) \\
973(66.1)\end{array}$ & $\begin{array}{l}- \\
-\end{array}$ & $\begin{array}{c}203(13.8) \\
- \\
92(6.3) \\
-\end{array}$ \\
\hline \multicolumn{4}{|l|}{ Education } \\
\hline $\begin{array}{c}\text { What is your collage degree major? } \\
\text { Social Science, Art, or Humanities } \\
\text { Criminal Justice or Legal Studies }\end{array}$ & $\begin{array}{l}603(41.0) \\
749(50.9)\end{array}$ & $\begin{array}{l}- \\
-\end{array}$ & $\begin{array}{c}119(8.1) \\
-\end{array}$ \\
\hline \multicolumn{4}{|l|}{ Political and Religious Orintation } \\
\hline $\begin{array}{l}\text { Rate your basic political orientation } \\
\text { Extremely liberal } \\
\text { Liberal } \\
\text { Slightly liberal } \\
\text { Moderate } \\
\text { Slightly conservative } \\
\text { Extremely conservative }\end{array}$ & $\begin{array}{c}135(9.2) \\
448(30.5) \\
191(13.0) \\
347(23.6) \\
128(8.7) \\
16(1.19\end{array}$ & $\begin{array}{l}- \\
- \\
- \\
- \\
- \\
-\end{array}$ & $\begin{array}{c}92(6.3) \\
- \\
- \\
- \\
- \\
-\end{array}$ \\
\hline
\end{tabular}


Abu MBoka, Sriram Chintakrindi, Chau-Pu Chiang, Phyllis Gerstenfeld, Dorothy McClellan, Irma Kovčo Vukadin: Classical Criminological Perspective and Attitudes Toward Same-Sex Rights

Table 3. Descriptive Statistics for Control Variables

\begin{tabular}{|c|c|c|c|}
\hline \multirow{2}{*}{\multicolumn{4}{|c|}{ To what extent does religion play a role in your }} \\
\hline & & & \\
\hline Not at all & $293(19.9)$ & - & $92(6.3)$ \\
\hline Not much & $397(27.0)$ & - & - \\
\hline A fair amount & $456(31.0)$ & - & - \\
\hline A great deal & $233(15.8)$ & - & - \\
\hline \multicolumn{4}{|c|}{ How frequently do you attend religious } \\
\hline Not religious & $291(19.8)$ & - & $95(6.5)$ \\
\hline Almost never & $502(34.1)$ & - & - \\
\hline Once a month & $220(15.0)$ & - & - \\
\hline Two or three times a month & $144(9.8)$ & - & - \\
\hline Once a week & $177(12.0)$ & - & - \\
\hline More than once a week & $42(2.9)$ & - & - \\
\hline \multicolumn{4}{|l|}{ Location of Respondent } \\
\hline \multicolumn{4}{|l|}{ Geographic Region } \\
\hline North America & $818(55.6)$ & - & - \\
\hline Eastern Europe & $484(32.9)$ & - & - \\
\hline Asia & $87(5.9)$ & - & - \\
\hline Other & $8285.6)$ & - & - \\
\hline \multicolumn{4}{|l|}{ Punitiveness } \\
\hline Support for punitive punishments & - & $100.16812 .38)$ & - \\
\hline
\end{tabular}

In table 3 we present the descriptive statistics of the control variables that we use to measure and analyze the data from our survey respondents $(n=1471)$. Our data was overwhelmingly collected from respondents who have the following characteristics: $71 \%$ male, $82 \%$ heterosexual, $50.9 \%$ have a criminal justice or legal education, 53\% slightly to extremely liberal political orientation, $46.8 \%$ place a fair amount to great deal of importance in their religious beliefs, $55.6 \%$ are from North America, and for support of punitive punishment policies they score an average of 100.16 with a standard deviation of 12.38. These descriptive statistics are important to understand as we proceed to analyze the data because they provide us not only with a baseline observation of the sociodemographic characteristics of our survey respondents, but they also provide us with feedback for understanding the limitations of our survey sample group and allow us to identify possible sampling biases which may impact our results. As we proceed to examine the relationship 
Abu MBoka, Sriram Chintakrindi, Chau-Pu Chiang, Phyllis Gerstenfeld, Dorothy McClellan, Irma Kovčo Vukadin: Classical Criminological Perspective and Attitudes Toward Same-Sex Rights

between support for the classical criminological perspective and attitudes towards homosexual rights, we also need to control for the possibility of spurious relationships, by examining the impact of third variables in our final statistical models.

Based on our examination of the previous literature, the specification of our research question and the formulation of our hypotheses, we assume that the classical criminological perspective emphasizes support for rational decision-making that promotes social and legal rights for individuals, so long as those rights do not cause harm to others. For our hypotheses, we specifically argue, that individuals who support the classical criminological perspective will also support homosexual rights due to its socio-legal consequences. However, there exists the possibility that sociodemographic characteristics are deeply-rooted in biological and socio-cultural constraints which may distort or eliminate our inferred relationship between support for the classical criminological perspective and attitudes towards homosexual rights. In fact, political and religious orientation characteristics may play an equal or more power role in shaping an individual's attitude towards homosexual rights, than their criminological perspective, because of the influence that politics and religion has historically had on shaping the norms and values of social groups and individuals (Durkheim, 2014). 


\section{BIVARIATE CORRELATION OF PREDICTORS, CONTROLS, AND OUTCOMES}

Table 4. Bivariate Correlations for Attitudes toward Homosexual Rights and Support for Classical Criminological Perspectives

Bivariate Correlations between the main Outcome variables and Studied Independent variables $(\mathrm{N}=1471)$

1

2

3

1. Crime is the product of a personal free will. (Classical Criminological Theory)

2. The main reason why people break the law is that they figure they can get away with it. (Classical Criminological Theory)

3. Factor Score Outcomes for Positive Attitude Statements towards Homosexual Rights

$390 * \star$ towards Homosexual Rights

$\begin{array}{lll}.125^{\star *} & .159^{\star *} & -.758^{* *}\end{array}$ ${ }^{*} p<0.05,{ }^{* *} p<0.01,{ }^{* \star *} p<0.001$

In Table 4, we present our bivariate analysis results which show a strong and positive correlation between the two classical criminological perspective variables in statements 1 and 2 $(r=.390, p<0.01)$. This relationship indicates that survey respondents who agree with the statement that "crime is the product of a person's free will" also agree with the statement that "the main reason why people break the law is because they can get away with it." 
Abu MBoka, Sriram Chintakrindi, Chau-Pu Chiang, Phyllis Gerstenfeld, Dorothy McClellan, Irma Kovčo Vukadin: Classical Criminological Perspective and Attitudes Toward Same-Sex Rights

Next, we examine the relationship between our classical criminological theoretical statements and our factor score outcomes examining attitudes towards homosexual rights. Our results show a significant negative correlation between variables 1 and $3(r=-.181, p<0.01)$. More specifically, we observe that survey respondents who agree with the statement that "crime is the product of a person's free will" disagree with the factor score outcomes for positive attitude statements towards homosexual rights. Therefore, we observe an inverse relationship between support for the classical criminological perspective and support for homosexual rights, which is contrary to our first hypothesis.

Additionally, we observe that there is a statistically significant positive correlation between theoretical variable 1 and variable 4, factor scores for negative attitude statements towards homosexual rights $(r=.125, p<0.01)$. More specifically, we observe that survey respondents who agree with the statement that "crime is the product of a person's free will" also agree with negative attitude statements towards homosexual rights. Therefore, we observe a strong positive relationship between support for the classical criminological perspective and disagreement with homosexual rights. This finding is also contrary to our second hypothesis.

Next, we examine the relationship between the classical criminological statement variable 2 and attitudes towards homosexual rights. The result in table 4, indicate that there is a statistically significant negative correlation between theoretical variables 2 and $3(r=-.191, p<0.01)$. More specifically, we observe that survey respondents who agree with the statement that "the main reason why people break the law is because they can get away with it" disagree with the factor score outcomes for positive attitude statements towards homosexual rights. Therefore, we observe an inverse relationship between support for the classical criminological perspective and support for homosexual rights, which is contrary to our first hypothesis.

Finally, we observe that there is a statistically significant positive correlation between variables 2 and $4(r=.159, p<0.01)$. More specifically, we observe that survey respondents who agree with the statement that "the main reason why people break the law is because they can get away with it" also agree with negative attitude statements towards homosexual rights. Therefore, we 
Abu MBoka, Sriram Chintakrindi, Chau-Pu Chiang, Phyllis Gerstenfeld, Dorothy McClellan, Irma Kovčo Vukadin: Classical Criminological Perspective and Attitudes Toward Same-Sex Rights

observe a strong positive relationship between support for the classical criminological perspective and disagreement with homosexual rights. This finding is also contrary to our second hypothesis.

Given, that our correlation analysis reveals that our initial findings are contrary to our proposed hypotheses, we believe that further exploratory analysis using multivariate models are needed to decompose and identify any control variables that may be affecting the relationship between support for the classical criminological perspective and attitudes towards homosexual rights. We infer that by examining sociodemographic control variables, we will identify characteristics that play a strong and significant role in influencing attitudes towards homosexual rights. 


\section{MULTIVARIATE ANALYSIS OF PREDICTORS, CONTROLS, AND OUTCOMES}

Table 5. Multiple Regression Analysis for Attitudes Towards Homosexual Rights

\begin{tabular}{|c|c|c|}
\hline & & \multirow{3}{*}{$\begin{array}{c}\text { Model } 2 \\
\text { B }\end{array}$} \\
\hline & & \\
\hline Variable (Groupings) & B & \\
\hline Age & 0.001 & $0.007^{* *}$ \\
\hline Gender (Male $=1$ ) & $-0.143^{\star *}$ & 0.086 \\
\hline What is your sexual orientation? (heterosexual $=1$ ) & $-0.354^{\star *}$ & 0.207 \\
\hline Do you have any gay or lesbian friends? (yes $=1$ ) & $0.503^{* * *}$ & $-0.553^{* * *}$ \\
\hline $\begin{array}{l}\text { What is your collage degree major? (Criminal Justice and } \\
\text { Legal Sudies }\end{array}$ & $-0.154^{\star \star}$ & $0.166^{\star \star}$ \\
\hline Rate your basic political orientation & $-0.190^{\star \star *}$ & $0.213^{* \star *}$ \\
\hline To what extent does religion play role in your life? & $-0.139 * \star \star$ & $0.097^{* *}$ \\
\hline How frequently do you attend religious services? & $-0.081^{\star *}$ & $0.103^{\star * *}$ \\
\hline \multicolumn{3}{|l|}{ North America (reference) } \\
\hline Estern Europe (yes = 1) & $-0.286^{\star \star \star}$ & $0.277^{* \star *}$ \\
\hline Asia (yes = 1) & 0.138 & -0.172 \\
\hline Other (yes = 1) & -0.101 & 0.043 \\
\hline Support for punitive punishments & -0.003 & 0.004 \\
\hline Crime is the product of a person's free will. & -0.022 & -0.038 \\
\hline $\begin{array}{l}\text { People break the law is that they figure they can get away } \\
\text { with it. }\end{array}$ & 0.001 & -0.014 \\
\hline R-Square & 0.424 & 0.424 \\
\hline $\mathrm{F}$ & $62.339 * * *$ & $62.332^{* * *}$ \\
\hline
\end{tabular}


Abu MBoka, Sriram Chintakrindi, Chau-Pu Chiang, Phyllis Gerstenfeld, Dorothy McClellan, Irma Kovčo Vukadin: Classical Criminological Perspective and Attitudes Toward Same-Sex Rights

The results of the regression analysis of factor score outcomes for positive attitude statements towards homosexual rights shown in Table 5 represents a statistically significant model for predicting factor score outcomes for positive attitude statements towards homosexual rights when entering all of the predictor and control variables in the final model $(p<0.001)$. The R-square for model 1 indicates that the predictors and controls variable explain 42.4 percent of the variance in the outcome for model 1. Our R-square for model 1 indicates that our predictor and control variables provide a strong and robust model for examining our outcome variable.

Furthermore, being male results in .143 units less in the factor score outcome than females $(p<0.01)$, and being heterosexual results in .354 units less in the factor score outcome than being homosexual $(p<0.01)$. These findings show that males and heterosexuals are significantly less likely to have positive attitudes towards homosexual rights compared to females and homosexuals. Having homosexual friends results in .503 units more in the factor score outcome than those without homosexual friends $(p<0.001)$. This finding shows that individuals with homosexual friends are more likely to have a positive attitude towards homosexual rights.

Also, we observe that being a criminal justice or legal studies major results in .154 units less in the factor score outcome than those who are humanities, arts, or social science major $(p<0.01)$. This finding shows that individuals with a criminal justice or legal studies education are far less likely to have a positive attitude towards homosexual rights compared to individuals with a humanities, arts, or social science education.

A one unit increase in political orientation results in a .190 unit decrease in the factor score outcome $(p<0.001)$, a one unit increase in religious importance results in a .193 unit decrease in the factor score outcome $(p<0.001)$. A one unit increase in frequency of religious attendance results in a .081 unit decrease in factor score outcome $(p<0.01)$, and being from Eastern European results in .286 units decrease in the factor score outcome than being a North American $(p<0.001)$. Also, we observe that the more conservative an individual is, the less likely they are to have a positive attitude towards homosexual rights compared to liberal leaning individuals. Finally, we observe that individuals who indicated that they are from Eastern Europe have significantly less positive attitudes towards homosexual rights compared to individuals from North America. 
Abu MBoka, Sriram Chintakrindi, Chau-Pu Chiang, Phyllis Gerstenfeld, Dorothy McClellan, Irma Kovčo Vukadin: Classical Criminological Perspective and Attitudes Toward Same-Sex Rights

Next, the results of the regression analysis of factor score outcomes for negative attitude statements towards homosexual rights, in Table 5, shows a statistically significant model for predicting factor score outcomes for negative attitude statements towards homosexual rights when entering all of the predictor and control variables into the final model $(p<0.001)$. The R-square for model 2 indicates that our predictor and control variables explain 42.4 percent of the variance in the outcome for model 2. Our R-square for model 2 indicates that our predictor and control variables provide a strong and robust model for examining our outcome variable.

Furthermore, we observe that a one unit increase in age results in a .007 unit increase in the factor score outcome $(p<0.01)$, having homosexual friends results in .553 unit decrease in the factor score outcome than those without homosexual friends $(p<0.001)$, and being a criminal justice or legal studies major results in .166 unit increase in the factor score outcome than those who are a humanity, arts, or social science major $(p<0.01)$. We observe that as age increases, individuals have more negative attitudes towards homosexual rights. Individuals with homosexual friends have significantly decreased negative attitudes towards homosexual rights compared to individuals without homosexual friends. Those with criminal justice or legal education have significantly higher negative attitudes towards homosexual rights compared to those with an education in humanities, arts, and social science.

Also, we observe that a one unit increase in political orientation results in a .213 unit increase in the factor score outcome $(p<0.001)$, and a one unit increase in religious importance results in a .097 unit increase in the factor score outcome $(p<0.01)$. A one unit increase in frequency of religious attendance results in a 103 unit increase in factor score outcome $(p<0.001)$, and being from Eastern Europe results in .277 units increase in the factor score outcome than being from North America $(p<0.001)$. These findings indicate that the more conservative and religiously oriented an individual is, the more likely they are to have a higher negative attitude towards homosexual rights compared to individuals who are liberal and secular. Finally, we find that individuals from Eastern Europe are more likely to have negative attitudes towards homosexual rights compared to individuals from North America. 
Abu MBoka, Sriram Chintakrindi, Chau-Pu Chiang, Phyllis Gerstenfeld, Dorothy McClellan, Irma Kovčo Vukadin: Classical Criminological Perspective and Attitudes Toward Same-Sex Rights

\section{DISCUSSION}

Our results show a contradiction between both our theoretical assumptions and our proposed hypotheses regarding the relationship between support for the classical criminological perspective and attitudes towards homosexual rights. In our bivariate analysis, using correlation tests, we observe that respondents who support the classical criminological perspective statements generally do not support positive attitude statements towards homosexual rights. The findings from our bivariate analysis indicate that individuals who support the classical criminological perspective generally have a disagreeing attitude with homosexual rights. These findings run contrary to our understanding of the extant literature and our specification of the hypotheses for this study. We assume that those individuals who support the classical criminological perspective are generally proponents of individual social and legal rights. Furthermore, as our analysis proceeded, we consistently observed findings that run contrary to our proposed hypotheses, in which those individuals who support the classical criminological perspective in fact have negative attitudes towards homosexual rights.

Although our bivariate findings are important in and of itself, we needed further confirmation that the relationship between support for the classical criminological perspective and attitudes towards homosexual rights remains robust even when including sociodemographic control variables into the model. Interestingly, we find that support for the classical criminological perspective and its relationship to attitudes towards homosexual rights is equally, if not more so, influenced by sociodemographic variables, such as, gender, homosexual friends status, education background, political and religious orientation, and geographical location.

In our multivariate analysis, using the multiple regression statistical approach, we demonstrate that when entering control variables into our model the relationship between support for the classical criminological theory statements and factor score outcomes related to attitudes towards homosexual rights disappears completely. Instead, the results consistently show that the strongest control variables for predicting attitudes towards homosexual rights across both of our statistical models are: homosexual friend status, college major, political orientation, importance of 
Abu MBoka, Sriram Chintakrindi, Chau-Pu Chiang, Phyllis Gerstenfeld, Dorothy McClellan, Irma Kovčo Vukadin: Classical Criminological Perspective and Attitudes Toward Same-Sex Rights

religion, frequency of religious attendance, and being from Eastern Europe. Moreover, we found that respondents with homosexual friends are more likely to support positive attitude statements towards homosexual rights. Respondents who identify as criminal justice majors and those who are ideologically conservative are the less likely to support positive attitude statements towards homosexual rights. Also, our results found that the more important religion is to respondents and the more frequently respondents attend religious services the less likely they are to support positive attitude statements towards homosexual rights. Respondents from Eastern Europe are less likely to support positive attitude statements towards homosexual rights, compared to respondents from North America.

Our findings suggest that sociodemographic considerations related to gender, educational background, geographical location, political ideology, and religious orientation are stronger predictors of attitudes towards homosexual rights, rather than support for the classical criminological perspective held by respondents. These findings are highly important because they contribute to the collective body of knowledge regarding our understanding of social attitudes towards homosexual rights in the fields of criminal justice and criminology. The primary reason we believe these findings are important is because our theoretical assumptions regarding the classical criminological perspective as a theory that emphasizes personal accountability, rational decision making, and individual legal and social rights is inconsistent with our findings.

Instead, we observe in our initial bivariate analysis that those individuals who support the classical criminological perspective are less likely to have positive attitudes towards homosexual rights is misleading and may lead to incorrect inferences about intolerance or extreme bias within our criminal justice system regarding attitudes towards of homosexual rights. However, upon further investigation using multivariate analysis, we get a clearer understanding of the true latent relationships underlying our initial observation. Instead, our multiple regression analysis reveals: (1) that there is no statistically significant relationship between support for the classical criminological perspective and attitudes towards homosexual rights and (2) that sociodemographic variables are a far more robust, significant, and consistent predictor of attitudes towards homosexual rights compared to the classical criminological perspective statements. These findings taken together reveal considerable insights into the factors that shape the attitudes towards homosexual rights among 
Abu MBoka, Sriram Chintakrindi, Chau-Pu Chiang, Phyllis Gerstenfeld, Dorothy McClellan, Irma Kovčo Vukadin: Classical Criminological Perspective and Attitudes Toward Same-Sex Rights

social groups. Our findings suggest that the most consistent indicators for predicting attitudes towards homosexual rights among respondents in our sample is their educational background, political and religious orientation, and geographical location. These findings demonstrate the need for considerably more research regarding the influence of criminological theoretical perspectives on attitudes towards social and legal rights.

\section{CONCLUSION}

This study examined the degree to which perspectives of college students and faculty aligned with the classical criminological theoretical perspective would support public policy responses to homosexual rights. Our results contradict our original hypotheses that individuals who support the classical criminological perspective were more likely to have positive attitudes towards homosexual social and legal rights. Our bivariate analysis reveals that the classical criminology perspective did not support positive attitudes toward same-sex rights. Furthermore, our multivariate analysis reveals that the relationship between support for the classical criminological perspective and attitudes towards homosexual rights is eliminated once sociodemographic control variables are added to the final models.

We speculate that respondents who believed "crime is the product of a person's free will" and "the main reason why people break the law is that they figure they can get away with it" will also report disagreeing or strongly disagreeing with notions that the laws regarding private consenting of same-sex behavior should be loosened, homosexuals should be free from job discrimination, they should have the same rights as heterosexual couples to adopt children, homosexuals should be able to teach, and same-sex marriage. One proposed explanation regarding our findings from our bivariate analysis is that people who support the classical criminological perspective are more likely to be politically conservative and religious; we hypothesize that these two set of characteristics predict disapproval of homosexuality and have an increased probability of disagreeing with it. However, future research is needed to confirm this hypothesis which is beyond the scope the present study. 
Abu MBoka, Sriram Chintakrindi, Chau-Pu Chiang, Phyllis Gerstenfeld, Dorothy McClellan, Irma Kovčo Vukadin: Classical Criminological Perspective and Attitudes Toward Same-Sex Rights

Also, we recognize that alternative explanations could be that agreement with the statements with the classical criminological perspective is not a good measurement of a person's academic socialization but rather a reflection of commonly held and shared views of criminal and delinquent behaviors permeated in mass media and long held public policies. However, we recommend that future research explores correlations between attitudes toward same-sex interactions and rights and other sociological variables such as gender, college major, political and religious orientation and regional differences for predicting support for homosexual rights. 
Abu MBoka, Sriram Chintakrindi, Chau-Pu Chiang, Phyllis Gerstenfeld, Dorothy McClellan, Irma Kovčo Vukadin: Classical Criminological Perspective and Attitudes Toward Same-Sex Rights

\section{REFERENCES}

Banks, A. (2014): "LGBT rights: the fight is far from over." The Guardian. Available at http://www. theguardian.com/ [accessed 3 June 2016]

Bisexual, and Transgender People Among Heterosexual College Students: Informing Socially

Bradley, A. (2010): Positive rights, negative rights and health care. Journal of Medical Ethics, 36, $12,838-841$.

Carroll, A. , Itaborahy, L.P. (2005): State Sponsored Homophobia 2005. A World Survey of Laws: criminalisation, protection and recognition of same-sex love. Geneva, International lesbian, gay, bisexual, trans and intersex association. 10th edition.

Chamie, J., Mirkin, B. (2011): Same-Sex Marriage: A New Social Phenomenon. Population and Development Review, 37, 3, 529-551.

David, L. (2014): A Principled Approach to the Positive/Negative Rights Debate in Canadian Constitutional Adjudication. Constitutional Forum, 23 (1), 41-46.

Durkheim, E. (2014): The division of labor in society. Simon and Schuster

Gaines, N. S., J. C. Garand, J.C. (2010): Morality, Equality, or Locality: Analyzing the Determinants of Support for Same-sex Marriage. Political Research Quarterly, 63 (3), 553-567.

Gerstenfeld, P., Chiang, C., MBoka, A., Chintakrindi, S., Werling, R., Gao, H., Matravers, A., McClellan, D., Vukadin Kovčo, I. (2015): Comparative Study of Student Attitudes Towards Punitiveness and Gay and Lesbian Issues Dataset. California State University, Stanislaus; Texas A \& M University, Corpus Christi; and University of Zagreb.

Green, S. K. (2007): Religious Liberty as A Positive and Negative Right. Albany Law Review, 70, 4, 1453-1472. 
Abu MBoka, Sriram Chintakrindi, Chau-Pu Chiang, Phyllis Gerstenfeld, Dorothy McClellan, Irma Kovčo Vukadin: Classical Criminological Perspective and Attitudes Toward Same-Sex Rights

Hackl, A. M., C. R. Boyer, et al. (2013): From "gay marriage controversy" (2004) to endorsement of same-sex marriage (2012): Framing bisexuality in the marriage equality discourse. Sexuality \& Culture, $17,3,512-524$.

Hirschl, R. (2000): "Negative" Rights vs. "Positive" Entitlements: A Comparative Study of Judicial Interpretations of Rights in an Emerging Neo-Liberal Economic Order. Human Rights Quarterly, 22, 4, 1060-1098.

Holzer, S. (2014): Natural Law, Natural Rights, and Same-Sex Civil Marriage: Do Same-Sex Couples Have a Natural Right to be Married? Texas Review of Law \& Politics, 19, 1, 63-79.

Just Policy Advocacy. Journal of Community Practice, 21, 203-227.

Koroma, S., Baker, A. (2005): How Uganda's LGBT Community Is Fighting for the Right to Exist." Time. Available at http://time.com/3910900/uganda-lgbt-transgender/ [accessed 8 June 2015]

Lewis, G. B. and S. S. Oh (2008): Public Opinion and State Action on Same-Sex Marriage. State \& Local Government Review, 40, 1, 42-53.

Maiese, M. (2013): Procedural Justice. Available at http://www.beyondintractability.org/essay/ procedural-justice [accessed 28 September 2015]

McCarthy, J. (2015): Record-High 60\% of Americans Support Same-Sex Marriage. Available at http://www.gallup.com/poll/183272/record-high-americans-support-sex-marriage. aspx [accessed 8 June 2015]

Obergefell et al. v. Hodges, Director, Ohio Department of Health, et al. 576 US (2015): Supreme Court of the United States. Available at http://www.equalrightstrust.org/files/ertdocs/ Equal\%20Rights\%20Trust\%20Case\%20Summary,\%200bergefell\%20et\%20al.\%20 v\%20Hodges,\%20Director,\%200hio\%20Department\%20of\%20Health,\%20el\%20 al.\%20576\%20US.pdf [accessed 7 June 2016]

Solomon, R. C., Murphy, M.C. Eds. (2000): What is Justice?: Classic and Contemporary Readings. New York, Oxford University Press. 
Abu MBoka, Sriram Chintakrindi, Chau-Pu Chiang, Phyllis Gerstenfeld, Dorothy McClellan, Irma Kovčo Vukadin: Classical Criminological Perspective and Attitudes Toward Same-Sex Rights

The United Nations. (1948). Universal Declaration of Human Rights. Available at http://www.un.org/en/universal-declaration-human-rights/ [accessed 7 June 2016]

UN General Assembly, International Covenant on Economic, Social and Cultural Rights, 16 December 1966, United Nations, Treaty Series, vol. 993, p. 3. Available at http:// www. refworld.org/docid/3ae6b36c0.html [accessed 7 June 2016]

Veigh, R. M., Diaz, M.E.D. (2009): Voting to Ban Same-Sex Marriage: Interests, Values, and Communities. American Sociological Review, 74, 6, 891-915.

Williams, R. (2011): Same-Sex Marriage and Equality.Ethical Theory and Moral Practice, 14, 5, 589-595.

Woodford, M. R., Atteberry, B., et al. (2013): Endorsement for Civil Rights for Lesbian, Gay. 